\title{
Delayed Inner Ear Maturation and Neuronal Loss in Postnatal Igf-1-Deficient Mice
}

\author{
Guadalupe Camarero, ${ }^{1}$ Carlos Avendaño, ${ }^{2}$ Carmen Fernández-Moreno, ${ }^{3}$ Angeles Villar, ${ }^{1}$ Julio Contreras, ${ }^{1,4}$ \\ Flora de Pablo, ${ }^{3}$ José G. Pichel, ${ }^{3}$ and Isabel Varela-Nieto ${ }^{1}$ \\ 1/nstituto de Investigaciones Biomédicas Alberto Sols, Consejo Superior de Investigaciones Científicas (CSIC), \\ Universidad Autónoma de Madrid (UAM), and '2Department of Morphology, Facultad de Medicina, UAM, 28029 Madrid, \\ Spain, ${ }^{3}$ Department of Cell and Developmental Biology, Centro de Investigaciones Biológicas, CSIC, 28006 Madrid, \\ Spain, and ${ }^{4}$ Department of Anatomy, Facultad de Veterinaria, Universidad Complutense de Madrid, 28040 Madrid, Spain
}

Insulin-like growth factor-1 (IGF-1) has been shown to play a key role during embryonic and postnatal development of the CNS, but its effect on a sensory organ has not been studied in vivo. Therefore, we examined cochlear growth, differentiation, and maturation in Igf-1 gene knock-out mice at postnatal days 5 (P5), P8, and P20 by using stereological methods and immunohistochemistry. Mutant mice showed reduction in size of the cochlea and cochlear ganglion. An immature tectorial membrane and a significant decrease in the number and size of auditory neurons were also evident at P20. IGF-1-deficient cochlear neurons showed increased caspase-3-mediated apoptosis, along with aberrant expression of the early neural markers nestin and Islet 1/2. Cochlear ganglion and fibers innervating the sensory cells of the organ of Corti presented decreased levels of neurofilament and myelin $\mathrm{P}_{0}$ in $\mathrm{P} 20$ mouse mutants. In addition, an abnormal synaptophysin expression in the somata of cochlear ganglion neurons and sensory hair cells suggested the persistence of an immature pattern of synapses distribution in the organ of Corti of these animals. These results demonstrate that lack of IGF-1 in mice severely affects postnatal survival, differentiation, and maturation of the cochlear ganglion cells and causes abnormal innervation of the sensory cells in the organ of Corti.

Key words: cochlear ganglion; insulin-like growth factor 1; IGF-1; myelination; neurogenesis; organ of Corti; synaptogenesis; stereology
Insulin-like growth factor-I (IGF-1), a 70 amino acid protein structurally related to insulin, has pleiotropic effects during brain embryonic and postnatal development (D'Ercole et al., 1996). IGF-1 and its membrane receptor are expressed in the developing nervous system in many areas related to projection neurons during axon growth and synaptogenesis. IGF-1 expression peaks in the mouse nervous system during the first two postnatal weeks and then declines gradually to low adult levels (Bondy, 1991). Studies disrupting the IGF-1 gene or IGF-type 1 high-affinity receptor confirmed the essential role of IGF-1 in brain development and maturation. IGF-1-deficient animals have severe growth deficiency, generalized organ hypoplasia, and diminished survival (Baker et al., 1993; Liu et al., 1993; Powell-Braxton et al.,

Received Feb. 26, 2001; revised June 25, 2001; accepted July 17, 2001.

This work was supported by Dirección General de Investigación y Desarrollo (Spain) Grants PM96.0075 and PM99-0111 (I.V.-N.) and PM97.0143 (F.d.P.) and Autonomous Community of Madrid grant CAM 08.5/0023/98 (C.A.). The fellowships to G.C. and C.F.-M. were awarded by the Ministerio de Educación y Cultura (Spain). We thank A. Efstratiadis for kindly providing the Igf-1 heterozygous mice and a DNA probe for genotyping, R. McKay for anti-nestin antibody, J.-M. Tomasi and M. H. Ryder for anti-myelin $\mathrm{P}_{0}$ antibody, and C. Gamallo for anti-synaptophysin antibody. The monoclonal antibody Islet- $1 / 2$ was obtained from the Developmental Studies Hybridoma Bank under the auspices of the National Institute of Child Health and Human Development and maintained by the University of Iowa, Department of Biological Sciences (Iowa City, IA). We also thank Vanessa Coronado for technical assistance. We are grateful to C. Vicario-Abejón, E. J. de la Rosa, and J. Rueda for comments on this manuscript.

J.G.P. and I.V.-N. contributed equally to this work.

Correspondence should be addressed to Isabel Varela-Nieto, Instituto de Investigaciones Biomédicas Alberto Sols, Consejo Superior de Investigaciones Científicas, Universidad Autónoma de Madrid, Arturo Duperier 4, 28029 Madrid, Spain. E-mail: ivarela@iib.uam.es.

J. G. Pichel's present address: Unidad de Investigación, Hospital de Mérida, Mérida, Badajoz, Spain.

Copyright $\odot 2001$ Society for Neuroscience $0270-6474 / 01 / 217630-12 \$ 15.00 / 0$
1993; Liu et al., 1998; Wang et al., 1999a). Their CNS phenotype includes reduced brain size, hypomyelination, reduced axonal diameters, and loss of selective neuronal populations (Beck et al., 1995; Cheng et al., 1998; Gao et al., 1999). Conversely, transgenic animals overexpressing IGF-1 have increased body and organ weight, and their brains are abnormal, primarily because of increased myelin (Carson et al., 1993; Ye et al., 1995; O'Kusky et al., 2000). A detailed study focused on the impact of IGF-1 deficit on a sensory organ is, however, still lacking.

In vitro studies have strongly suggested that IGF-1 is required for chicken inner ear organogenesis (León et al., 1995, 1999; Sanz et al., 1999a,b). IGF-1 is also expressed during maturation of the rat auditory system and in adult hair cells (Lee and Cotanche, 1996; Saffer et al., 1996). IGF-1 displays neuroprotective activity (Dore et al., 1997) and, in the rodent inner ear, IGF-1 increases hair cell regeneration (Oesterle et al., 1997; Staecker and Van de Water, 1998). In addition, a single case of a natural mutation of the Igf- 1 gene in a human showed growth failure and severe sensorineural deafness (Woods et al., 1996, 1997).

The inner ear is a complex sensory organ responsible for sound detection in vertebrates. The mechanosensory transduction in the organ of Corti (OC) involves the interaction of specialized sensory hair cells with the tectorial membrane. The cochlear ganglion contains the primary neurons that innervate the sensory epithelia of the OC via afferent dendrites and transduce electrochemical output to the brainstem. Reciprocally, efferent axonal fibers from the olivocochlear system innervate sensory cells (Berglund and Ryugo, 1987; Spoendlin, 1988). The onset and tuning of hearing depend on the correct relationship between the tectorial membrane and the hair cells and the proper innervation and 
synaptogenesis of the sensory epithelium (Romand et al., 1987; Rueda et al., 1996; Mu et al., 1997). Maturation of the cochlea during the first two postnatal weeks in rodents involves cellular differentiation and a massive rearrangement of afferent and efferent innervation (Rubel, 1978; Knipper et al., 1995).

Here we have studied whether IGF-1 participates in murine postnatal cochlear development and maturation. We found that mice lacking IGF-1 had a significant reduction in the size of the cochlea and cochlear ganglion, an immature tectorial membrane, a decrease in the number and size of auditory neurons, and a general delayed maturation in the innervation of the OC.

\section{MATERIALS AND METHODS}

Mice and genotyping. Heterozygous mice with a targeted disruption of the Igf-1 gene were kindly provided by Dr. Argiris Efstratiadis at Columbia University (New York, NY) (Liu et al., 1993). Animals were bred and maintained on a hybrid genetic background of MF1 and 129/sv mouse strains to increase nullizygous Igf-1 mutant survival (Liu et al., 1993). Heterozygous Igf- 1 mice $\left(I g f-1^{+1-}\right)$ were bred to generate litters with wild-type $\operatorname{Ig} f-1\left(\operatorname{Igf}-1^{+/+}\right), \operatorname{Igf}-1^{+/-}$and $\operatorname{Ig} f-1^{-/-}$progeny. The majority of null animals do not survive until adulthood, considering the mortality before postnatal day $20(\mathrm{P} 20)$ is $>80 \%$. We focused our study on normal Ig $f-1^{+1+}$ and homozygous mutants $I g f-1^{-1-}$ animals at P5, P8, and P20. Heterozygous mice were also studied, although they presented a highly variable phenotype and, therefore, these results are not routinely presented. For genotyping by Southern blot analysis, DNA was prepared from the tail tip following standard protocols (Hogan et al., 1994), and probed as previously described (Liu et al., 1993). All animal handling followed approved institutional protocols.

Fixation and histology. Mice were anesthetized with $\mathrm{CO}_{2}$ on dry ice (P5) or by intraperitoneal injection of $0.12 \mathrm{mg} / \mathrm{gm}$ ketamine hydrochloride (P20) and perfused transcardially with $4 \%$ paraformaldehyde in 0.1 M PBS. Heads were removed and processed for celloidin or paraffin embedding. For celloidin embedding, after removing skull vaults, heads were post-fixed for $3 \mathrm{~d}$ in the same fixative, decalcified in $0.3 \mathrm{M}$ EDTA, $\mathrm{pH} 6.3$, for $3 \mathrm{~d}(\mathrm{P} 5)$ or $7 \mathrm{~d}(\mathrm{P} 20)$ at room temperature, dehydrated in ethanol for $7 \mathrm{~d}$, and defatted in ether for $3 \mathrm{~d}$. Specimens were cut along the sagittal line and sequentially infiltrated in 2, 4, 6, and $12 \%$ lowviscosity nitrocellulose (Celloidin; Fluka, Buchs, Switzerland) dissolved in a 1:1 mixture of ethanol and ether. Celloidin blocks containing the hemicrania were prepared from fresh $12 \%$ solution hardened with chloroform vapors. Blocks were serially cut in $50-\mu \mathrm{m}$-thick sections using a sliding microtome, following different planes of section for each side: left hemicrania were sectioned along the sagittal plane and right hemicrania along the horizontal plane. Sections were collected and stored in $70 \%$ ethanol. For stereological observations, every second section was mounted and Nissl-stained using $1 \%$ cresyl violet. For some histological studies, additional thinner $(25 \mu \mathrm{m})$ celloidin sections were used. For paraffin embedding, temporal bones containing the inner ear were removed, post-fixed in buffered $4 \%$ paraformaldehyde for $2 \mathrm{~d}$, decalcified in 0.3 м EDTA, pH 6.3, dehydrated in ethanol, and embedded in paraffin. Serial $10 \mu \mathrm{m}$ sagittal sections were used for TUNEL labeling or immunohistochemical studies. At least four animals of each genotype were sampled for each assay.

Stereological analysis and statistics. Celloidin sections were used to obtain quantitative data on morphological parameters of the cochlea. We estimated the total volume of the cochlea and cochlear ganglion, the cochlear ganglion total neuron number, and the mean soma volume of ganglion neurons. No correction for shrinkage was introduced. All measurements were performed using an interactive computer system consisting of a high-precision motorized microscope stage, a $0.5 \mu \mathrm{m}$ resolution $z$-axis reader (microcator Heidenhain VZR 401), a solid-state video camera, and a high-resolution video monitor. The objectives used were a planachromatic X20 (Splan 20; Olympus, Hamburg, Germany) and a planapochromatic $100 \times$ oil immersion lens with a numerical aperture of 1.4 (S-Plan Apo 100; Olympus). The interactive test grids and control of the motorized stage were provided by the GRID general stereological software package (Olympus) running on an Amiga 2000 computer.

Every second celloidin section of the whole structure that contained the entire cochlea or the cochlear ganglion was selected for measuring their respective volumes $(\sim 10$ sections per inner ear). An unbiased estimate of the total volume $(V)$ of the cochlea, including the otic capsule, was obtained by point-counting using a uniform point grid, applying the principle of Cavalieri (Gundersen et al., 1988; Blasco et al., 1999). Following this principle, $V=t \cdot a(p) \cdot \Sigma P_{i}$, where $t$ is the mean distance between two sections $(t=0.1 \mathrm{~mm}), a(p)$ is the area associated to each test point $\left[a(p)=0.002028 \mathrm{~mm}^{2}\right]$, and $P_{i}$ is the number of points that fall within the cochlea on each section. The cochlear ganglion volume was estimated applying the same method and considering "ganglionar area" all groups of neurons with more than two juxtaposed neuron bodies.

The absolute number of neurons $(\mathrm{N})$, the mean cell body volume, and the distribution of individual volumes were obtained simultaneously in each cochlear ganglion, by means of the optical fractionator (Gundersen et al., 1988; West et al., 1991), which is a stereological development that combines the optical disector with a fractionator sampling scheme and the vertical planar rotator (Jensen and Gundersen, 1993; Tandrup et al., 1997; Lagares and Avendaño, 2000).

The method used for obtaining the absolute neuron number $(N)$ consisted in counting the cell nuclei that appeared within a series of systematically random-sampled volumes $\left(\Sigma Q^{-}\right)$and dividing it by the fraction of the total volume of the ganglion represented by the addition of the sampled volumes $\left(f_{T}\right), N=\left(\Sigma Q^{-}\right) \times 1 / f_{T}$. The fractionator sampling scheme was applied as follows: (1) every second section was used for counting $\left(f_{S}=1 / 2\right)$; (2) the cochlear ganglion was divided into fixed areas, the first of which was positioned at random; a stepping motor moved the microscope stage systematically to other locations at preestablished and fixed distances. The area of the disector frame covered $352 \mu \mathrm{m}^{2}$, which was a fraction $\left(f_{d}\right)$ of the total sampled area $\left(f_{d}=1 / 10\right)$. Finally, (3) the disector height was set at $20 \mu \mathrm{m}$, so the fraction of the total section thickness sampled was $f_{h}=20 / t$. The mean section thickness for each ganglion was estimated from the microcator readings of three or four measurements per section, performed by focusing from top to bottom surfaces of the tissue. The average $t$ for all ganglia was $48.7 \mu \mathrm{m}$. The total sampling fraction is the product of the fractions at each step of the sampling procedure, $f_{T}=f_{S} \times f_{d} \times f_{h}$. The optical disector (Sterio, 1984) was applied in each sampled field.

Neuronal nuclei were selected on the basis of cellular pyknosis, nucleus shape, and defined presence of nucleolus. Cells without a welldefined nuclear membrane and at least one nucleolus were excluded. All nuclei whose equator came into focus $10 \mu \mathrm{m}$ below the section surface and within the disector frame were counted, as were other nuclei coming into focus as the focal plane was lowered up to $30 \mu \mathrm{m}$ below the surface. Nuclei touching the lowest plane, or either of two predetermined adjacent sides of the rectangular disector frame, were not included in the count. The perikaryal volume of the same ganglion cells that were sampled for obtaining $N$ was estimated by means of the vertical planar rotator (Jensen and Gundersen 1993; Avendaño and Dykes, 1996). This procedure consists of positioning a grid of parallel and equidistant lines orthogonal to a "vertical" axis drawn through the nucleolus and parallel to the cutting direction. Because of the spiral course of the ganglion, the cell bodies revolve around the vertical axis. This effectively substitutes the use of various orientations of the cutting planes around the vertical axis, a requisite to guarantee isotropy in measuring designs that use "vertical" sections (Gundersen et al., 1988). The rotator allows estimation of the mean cell volume of the entire population $\left(V_{\mathrm{N}}\right)$, as well as plotting a distribution of neurons on the basis of body size (West, 1999). The precision of the estimations was evaluated by computing the coefficient of error as described for systematic random samples (Howard and Reed, 1998; Gundersen et al., 1988; Blasco et al., 1999). With this sampling scheme the coefficient of error was $<5 \%$ for cochlear and ganglion volume estimations and $12 \%$ for cell number. Individual mean volume estimates were computed for each ganglion. Cell volume distributions were computed for each size by dividing individual measurements into eight classes using both linear and logarithmic-converted scales. The population percentage of cells belonging to each class volume was calculated as the average of the percentage of cells belonging to that class in different mice. Student's $t$ test was used to assess significance of the data on volume and number of cells of the cochlea and cochlear ganglion. The Kruskal-Wallis test was applied to data on perikaryal volume.

Terminal deoxynucleotidyl transferase-mediated UTP nick end labeling, 4',6'-diamidino-2-phenylindole, and propidium iodide staining. Terminal deoxynucleotidyl transferase-mediated UTP nick end labeling (TUNEL) 
was performed following manufacturer's instructions (Roche Diagnostics, Mannheim, Germany), adapted to paraffin sections. Briefly, deparaffinized sections were permeated in $20 \mu \mathrm{g} / \mathrm{ml}$ of proteinase $\mathrm{K}$, for 15 min at $37^{\circ} \mathrm{C}$. Endogenous peroxidase was inhibited by treatment with $3.0 \% \mathrm{H}_{2} \mathrm{O}_{2}$ (Sigma, St. Louis, MO) in methanol. Sections were then incubated with the terminal deoxynucleotidyl transferase enzyme diluted $1: 20(\mathrm{v} / \mathrm{v})$ in the terminal deoxynucleotidyl-transferase buffer containing biotin-16-deoxy-UTP, for $1 \mathrm{hr}$ at $37^{\circ} \mathrm{C}$. Unspecific binding was then blocked by treatment with $3 \%$ BSA (Sigma) for $30 \mathrm{~min}$. TUNEL signal was visualized with an antibody coupled to peroxidase (Converted-Pod, 1:5 dilution; Roche Diagnostics), for $30 \mathrm{~min}$ at $37^{\circ} \mathrm{C}$. Signal development was performed with $0.5 \mathrm{mg} / \mathrm{ml}$ diaminobenzidine tetrahydrochloride (Sigma) and $0.01 \% \mathrm{H}_{2} \mathrm{O}_{2}$ and observed with an Olympus M021 light microscope. For 4',6'-diamidino-2-phenylindole (DAPI) staining, paraffin sections were mounted using $4 \mu \mathrm{g} / \mathrm{ml}$ DAPI (Sigma) to visualize pyknotic nuclei. Alternatively, sections were stained with propidium iodide $(10 \mu \mathrm{g} / \mathrm{ml})$ (Sigma) and observed with a Zeiss Axioscope fluo- rescence microscope or an MCR 1924 confocal microscope (Bio-Rad, Hemel Hempstead, Hertfordshire, UK).

Immunohistochemistry. Paraffin sections $(10 \mu \mathrm{m})$ of temporal bones from at least four $I g f-1^{+/+}$and $I g f-1^{-1-}$ mice were used. After deparaffination and rehydration in PBS, sections were incubated with a blocking solution of $0.1 \%$ Triton X-100 in PBS, containing either $1 \%$ BSA or $10 \%$ sheep serum. Samples were quenched in $0.6-1.5 \% \mathrm{H}_{2} \mathrm{O}_{2}$ and left overnight at $4^{\circ} \mathrm{C}$ in blocking solution containing different primary antibodies. Sources, dilution, and cell specificity of the antibodies used in this study were: anti-proliferative cell nuclear antigen (PCNA) mouse monoclonal (Concepta, Barcelona, Spain) (1:500); anti-caspase-3 activated mouse polyclonal (Srinivasan et al., 1998) (1:100); anti-Islet 1/2, mouse monoclonal (Developmental Studies Hybridoma Bank) (1:200); anti-Nestin 128, rabbit polyclonal (Lendahl et al., 1990) (1:500); anti-Neurofilament $200 \mathrm{kDa}$, mouse monoclonal (Diagnostic, Mannheim, Germany) (1:50); anti-synaptophysin, rabbit polyclonal (Dako, Copenhagen, Denmark)
Figure 1. Cochlear anatomy of the mouse genotypes analyzed and IGF-1 expression. Nissl staining of mid-modiolar celloidin sections of the cochlea at $\mathrm{P} 5(A, B)$ or $\mathrm{P} 20(C, D)$ in $I g f-1^{+/+}(A, C)$ and Igf-1 $1^{-1-}(B, D)$ mice. An increased thickness of the otic capsule cartilage and a dispersion of the fibers in the auditory branch of the eighth cranial nerve of $I g f-1^{-1}$ at P5 (star) were observed in all animals studied. Note the reduction in size of $I g f-1^{-1-} \mathrm{P} 20$ cochlea compared with the Igf-1 $1^{+/+}$P20 controls. IGF-1 immunohistochemical expression in the cochlea $(E)$ and cochlear ganglia $(F)$ of $\mathrm{P} 20 \operatorname{Igf}-1^{+/+}$mice. Asterisk in $E$ indicates the area shown in $F$; arrowheads in $F$ point to the subpopulation of IGF-1-positive neurons. The inset shows a magnification of the cochlear ganglion of $I g f-1^{-1-} \mathrm{P} 20$ animals $(G)$. C, Cochlear duct; $O$, otic capsule; $O C$, organ of Corti; $C G$, cochlear ganglion; VIII, eighth cranial nerve; $T M$, tectorial membrane; $S L$, spiral limbus; $S V$, stria vascularis. Scale bars: $A-D$, $650 \mu \mathrm{m} ; E, 600 \mu \mathrm{m} ; F, 55 \mu \mathrm{m} ; G, 10 \mu \mathrm{m}$.
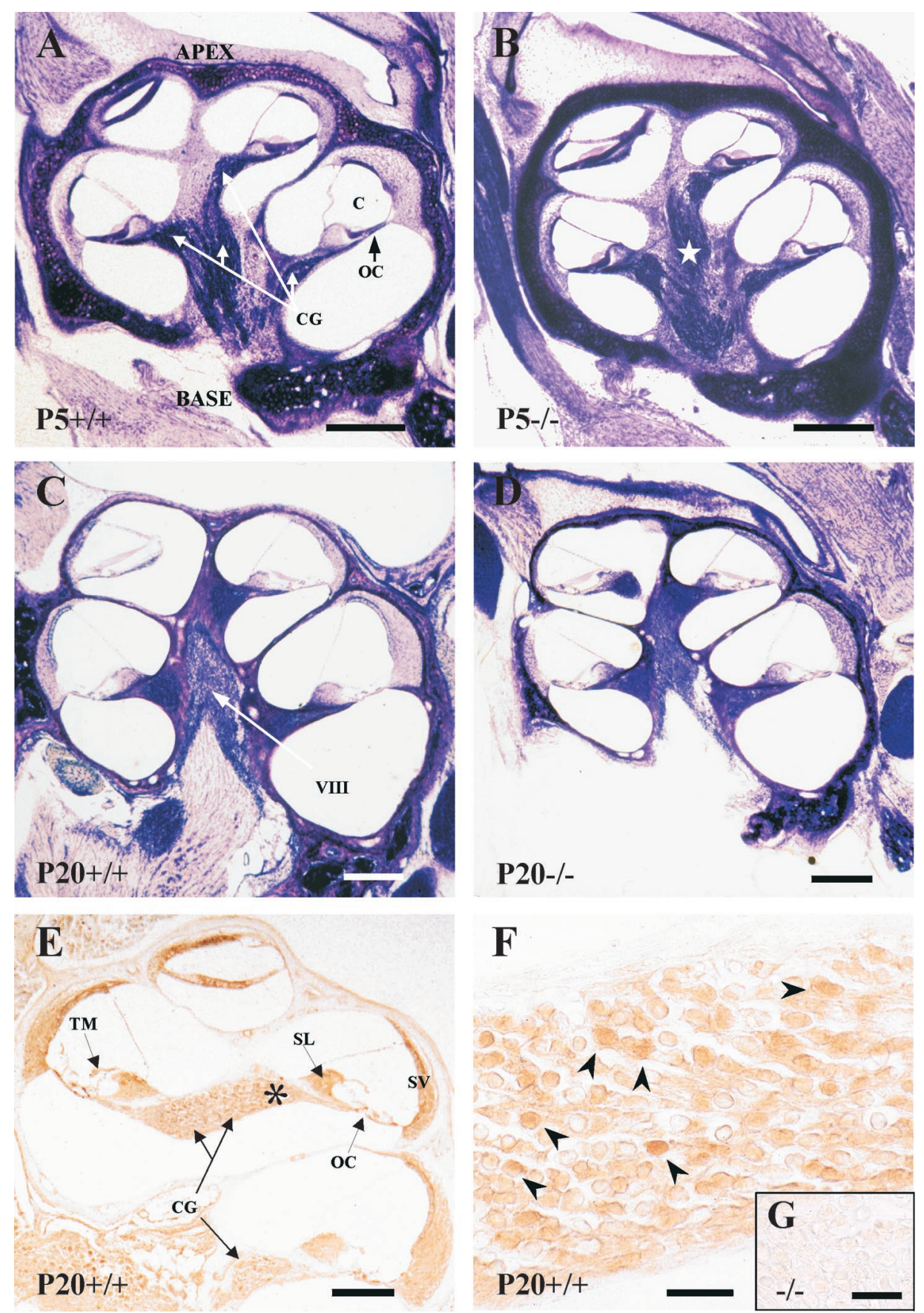


\begin{tabular}{|c|c|c|c|c|}
\hline Mouse number & Age & Body weight (gm) & Igf-1 genotype & $\begin{array}{l}\text { Mean cochlear } \\
\text { volume }\left(\mathrm{mm}^{3}\right)\end{array}$ \\
\hline 1 & P5 & 3.9 & $+/+$ & 1.10 \\
\hline 2 & P5 & 2.8 & $+/+$ & 1.68 \\
\hline 3 & P5 & 2.9 & $+/+$ & 1.30 \\
\hline Mean P5 Igf-1 $1^{+/+}$ & & $3.2 \pm 0.6$ & & $1.36 \pm 0.30$ \\
\hline 4 & P5 & 1.4 & $-1-$ & 1.39 \\
\hline 5 & P5 & 1.7 & $-1-$ & 1.32 \\
\hline 6 & P5 & 1.6 & $-1-$ & 1.00 \\
\hline Mean P5 Igf-1 $1^{-1-}$ & & $1.6 \pm 0.2^{a}$ & & $1.24 \pm 0.21^{b}$ \\
\hline 7 & $\mathrm{P} 20$ & 11.5 & $+/+$ & 2.21 \\
\hline 8 & $\mathrm{P} 20$ & 11.8 & $+/+$ & 2.07 \\
\hline 9 & $\mathrm{P} 20$ & 10.9 & $+/+$ & 2.03 \\
\hline 10 & P20 & 10.2 & $+/+$ & 2.37 \\
\hline 11 & $\mathrm{P} 20$ & 9.5 & $+/+$ & 1.99 \\
\hline Mean P20 $\lg f-1^{+/+}$ & & $10.8 \pm 0.9$ & & $2.13 \pm 0.16$ \\
\hline 12 & $\mathrm{P} 20$ & 5.2 & $-1-$ & 1.56 \\
\hline 13 & $\mathrm{P} 20$ & 4.0 & $-1-$ & 1.53 \\
\hline 14 & $\mathrm{P} 20$ & 3.7 & $-1-$ & 1.33 \\
\hline 15 & $\mathrm{P} 20$ & 5.1 & $-1-$ & 1.19 \\
\hline 16 & $\mathrm{P} 20$ & 5.4 & $-1-$ & 1.42 \\
\hline Mean P20 $\lg f-1^{-/-}$ & & $4.7 \pm 0.7^{c, d}$ & & $1.41 \pm 0.15^{c, d}$ \\
\hline
\end{tabular}

Values are expressed as mean \pm SD. The total volume of the cochlea includes the otic capsule. Mean values of the two cochleas per animal are presented. Data were obtained by applying the stereological principle of Cavalieri to point-counts obtained using a uniform grid, as described in Materials and Methods. Statistical analysis was performed using Student's $t$ test.

${ }^{a}$ Difference from P5 Igf- $1^{+/+} ; p<0.05$.

${ }^{b}$ Not significantly different from P5 Igf-1 ${ }^{+/+}$.

${ }^{c}$ Difference from P20 Igf- ${ }^{+/+} ; p<0.001$.

${ }^{d}$ Difference from P5 Igf-1 ${ }^{+/+} ; p<0.001$.
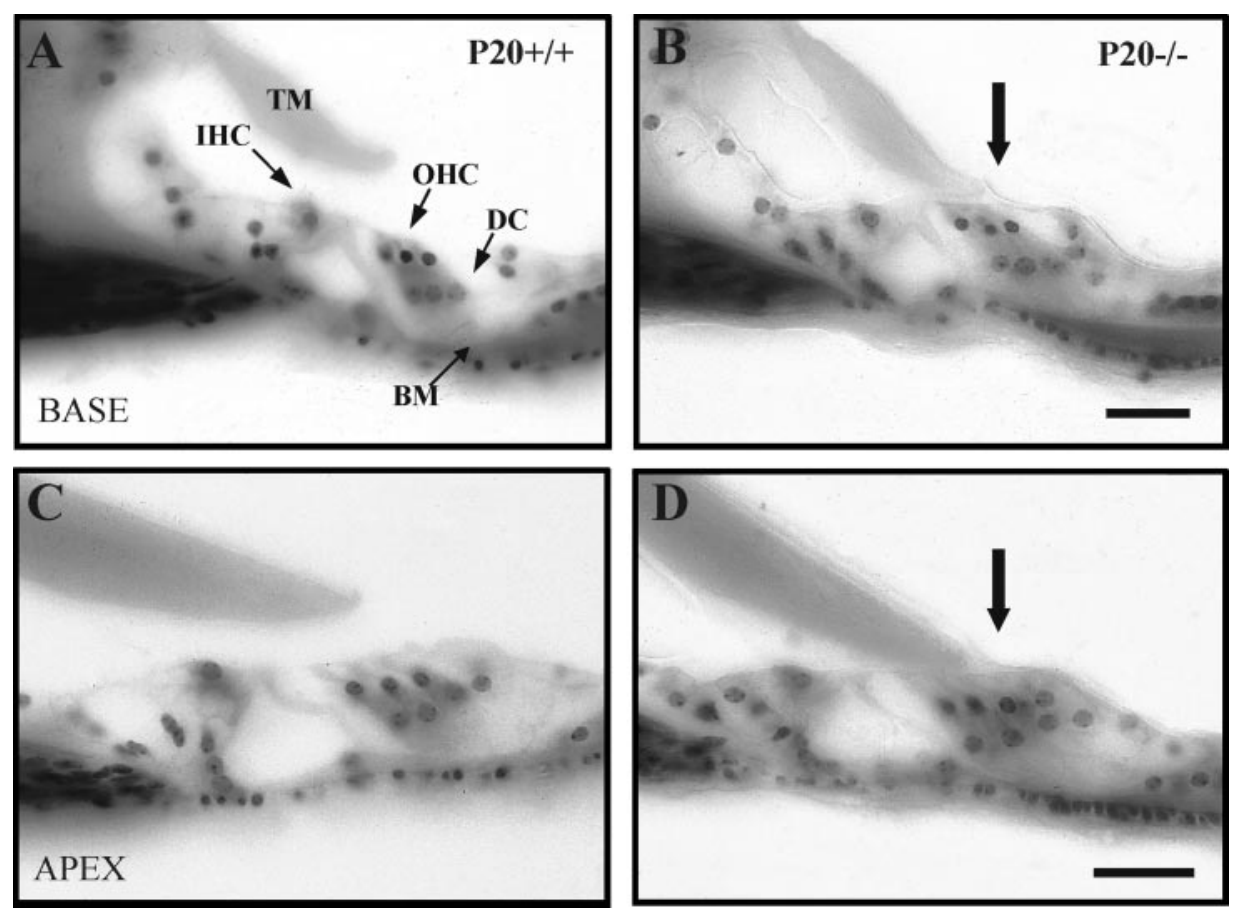

Figure 2. Altered morphology of the OC tectorial membrane in $\operatorname{Ig} f-1^{-1-}$ P20 mice. Nissl staining of celloidin-embedded cross sections of the OC of P20 Igf-1 $1^{+/+}(A, C)$ and $\operatorname{Igf}-1^{-/}$ $(B, D)$ animals. $A$ and $B$ show basal turns, whereas $C$ and $D$ show apical turns of the cochlea. Physical attachment of the tectorial membrane to the hair cells was noticed in all sections of P20 Igf-1 ${ }^{-1-}(B, D$, arrows). $B M$, Basilar membrane; $D C$, Deiters' cells; $I H C$, inner hair cells; $O H C$, outer hair cells; $T M$, tectorial membrane. Scale bars, $30 \mu \mathrm{m}$.

(1:100); anti-GFAP, rabbit polyclonal (Dako) (1:100); anti-Myelin $\mathrm{P}_{0}$, mouse monoclonal (Cao et al., 1996) (1:500); and anti-vimentin VIM3B4 mouse monoclonal (Colucci-Guyon et al., 1994) (Profer ImmunoDiagnostika, Heidelberg, Germany) (1:100). These molecules are markers for proliferative cells, apoptotic cells, young neurons, precursor cells, neurons, synapses, glial cells, myelin and immature neurons, respectively. Anti-IGF-I rabbit polyclonal UB3-189 (1:100) was from National Pituitary Agency (Baltimore, MD). After incubation with EnVision+ antimouse or anti-rabbit peroxidase-conjugated secondary antibodies (Dako, Copenhagen, Denmark) for $30 \mathrm{~min}$, peroxidase was reacted with 0.66 

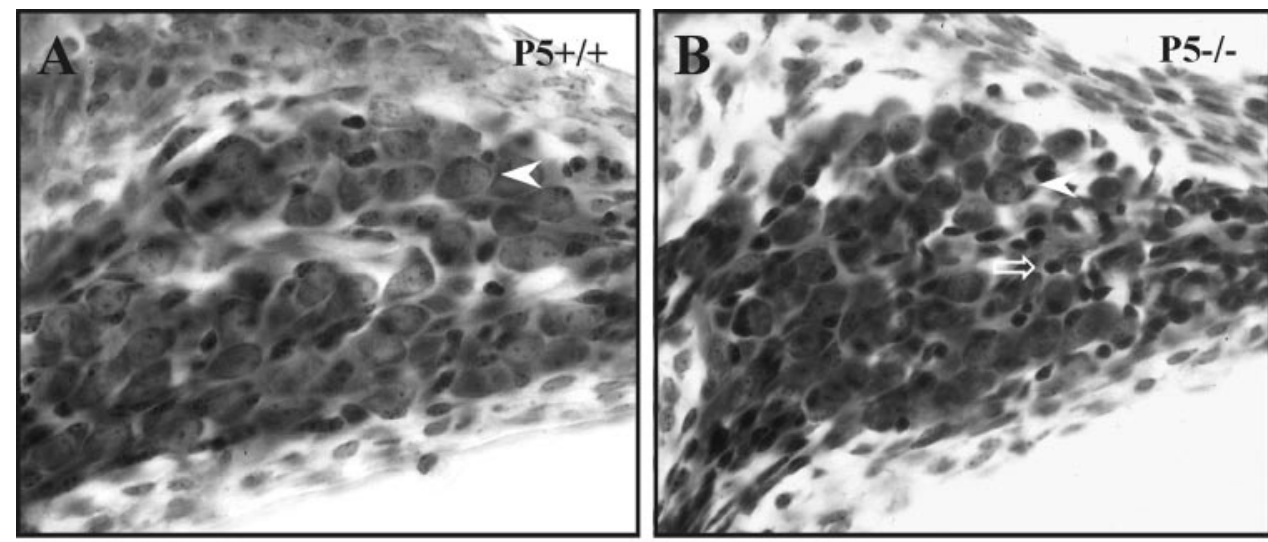

Figure 3. Altered cochlear ganglion morphology in Igf-1 $1^{-1-}$ mice. Nissl staining of the ganglion in the cochlear basal turn in $\operatorname{Igf-1^{+/+}}(A, C)$ and $\operatorname{Igf-1^{-1-}}(B, D)$ mice at P5 $(A, B)$ and P20 $(C, D)$. At P5, the cochlear ganglion and its neurons show similar morphology in both genotypes (arrowheads), except that Igf-1 ${ }^{-/-}$mouse also show a subtype of abnormally small, strongly chromaffinic cells (open arrow). At P20, ganglion cells are noticeably reduced both in size and number in Igf-1 $1^{-/-}$mice. This reduction, despite the presence of enlarged intercellular spaces (arrows), leads to a considerable decrease in the ganglion cross-sectional area. $E$ and $F$ show negative PCNA expression in the cochlear ganglion cells of P5 $I g f-1^{+/+}(E)$ and $I g f-1^{-/-}(F)$ mice. The inset $(G)$ shows a positive control of PCNA-positive cerebellum cells from the same section of P20 Igf-1 ${ }^{-1-}$ mouse shown in $F$. Scale bar, $30 \mu \mathrm{m}$.
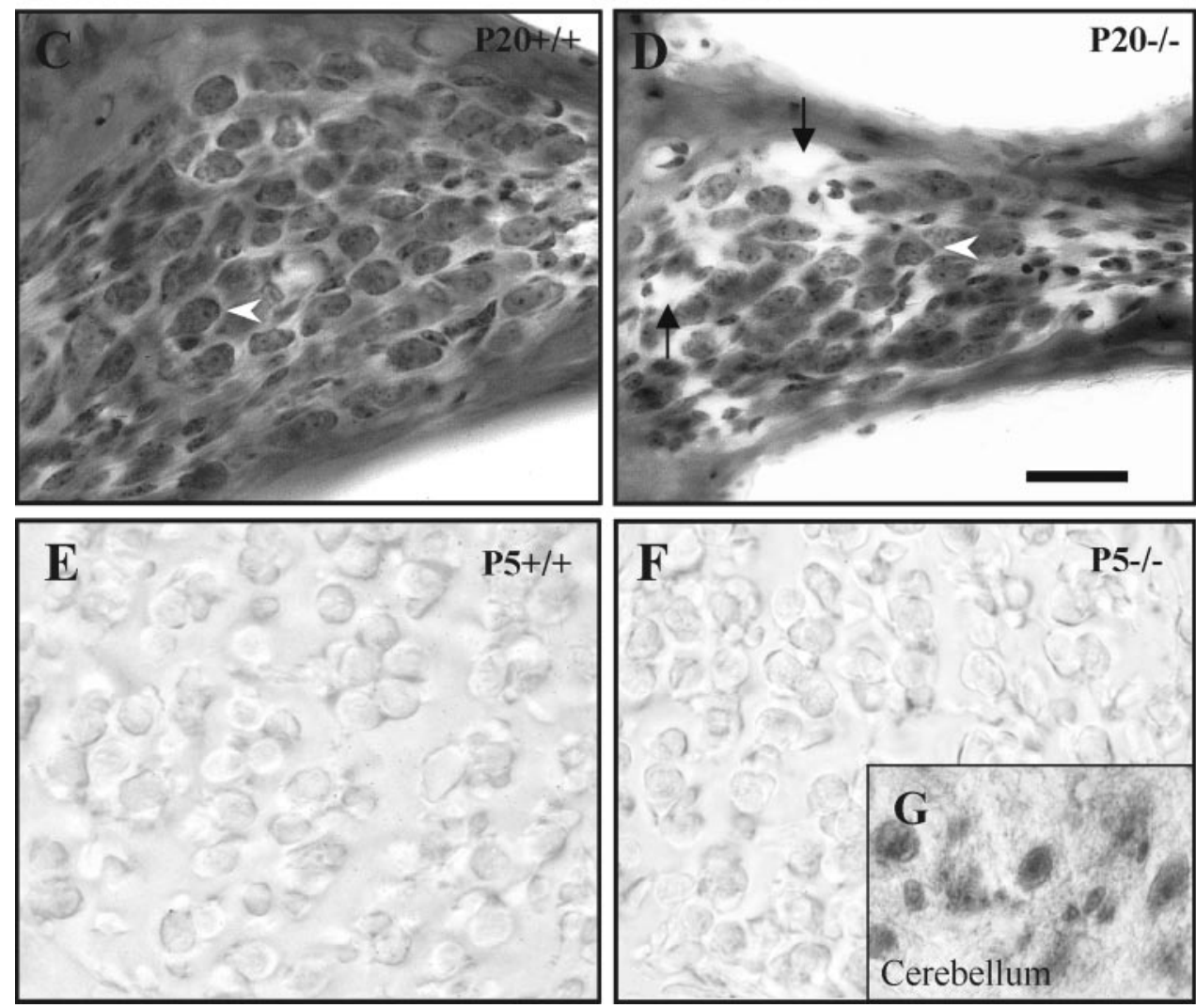

$\mathrm{mg} / \mathrm{ml}$ diaminobenzidine tetrahydrochloride (DAB) (Sigma) and 0.02\% $\mathrm{H}_{2} \mathrm{O}_{2}$ (Sigma).

\section{RESULTS}

\section{IGF-1 is required for normal postnatal development of cochlear structures}

To assess the effect of IGF-1 deficiency on the general morphology of the cochlea, we examined serial inner ear sections of normal $I g f-1^{+/+}$and mutant $I g f-1^{-/-}$mice at P5 and P20 (Fig. 1). P5 Igf- $1^{-/-}$animals showed a thicker cartilaginous otic capsule and a more disperse distribution of the fibers from the auditory branch of the eighth cranial nerve than the normal littermates (Fig. $1 A, B$ ). At P20, mutant cochleas displayed no major alteration in general gross anatomy, but a significant reduction in size was evident (Fig. 1D) when compared with normal mice (Fig. $1 C$ ). Figure 1, $E$ and $F$, shows positive immunolabel for IGF-1 in the cochlea and cochlear ganglion of normal mice at P20. IGF-1 is strongly expressed in a subpopulation of neurons of the co- chlear ganglion. Other structures in the cochlea, such as stria vascularis, spiral limbus, and support cells of the OC, presented also IGF-1 staining. A similar expression pattern was observed at P5 (data not shown). The lack of expression of IGF-1 in the cochlear neurons of null mice is shown in the inset (Fig. $1 G$ ) and is compared with positive wild-type neurons (Fig. $1 F$, arrowheads).

The most typical phenotypic characteristic of the $I g f-1$ null mutation is general growth retardation (Liu et al., 1993; Baker et al., 1993; Powell-Braxton et al., 1993). Therefore, the volume of the cochlea was calculated by a quantitative stereological analysis (Table 1). The body weight of $I g f-1^{-/-}$animals used in this study was reduced between 50 (P5) and 60\% (P20) relative to that of the $I g f-1^{+/+}$littermates, as previously published (Baker et al., 1993). In contrast, $I g f-1^{-1-}$ mice showed a nonsignificant reduction $9 \%$ in cochlear volume at P5 when compared with $I g f-1^{+/+}$ but a very significant $34 \%$ reduction (compare $1.41 \pm 0.15$ with $2.13 \pm 0.16 \mathrm{~mm}^{3}$ ) at P20 (Table 1, Fig. 1). This suggests that 
Table 2. Comparison of ganglion volume, neuronal number, and neuronal soma volume of cochlear ganglia

\begin{tabular}{|c|c|c|c|c|c|c|c|}
\hline & & \multicolumn{2}{|c|}{ Ganglion volume $\mathrm{e}^{a}\left(\mathrm{~mm}^{3}\right)$} & \multicolumn{2}{|c|}{$\begin{array}{l}\text { Number of neurons }{ }^{b} \\
\text { (in thousands) }\end{array}$} & \multicolumn{2}{|c|}{ Neuronal soma ${ }^{c}$ volume $\left(\mu \mathrm{m}^{3}\right)$} \\
\hline & & Mean & $\%$ variation $^{d}$ & Mean & $\%$ variation $^{d}$ & Mean & $\%$ variation $^{d}$ \\
\hline \multicolumn{8}{|l|}{ P5 } \\
\hline $\operatorname{Ig} f-1^{+/+}$ & $n=3$ & $0.046 \pm 0.009$ & 0 & $16.1 \pm 0.7$ & 0 & $506 \pm 42$ & 0 \\
\hline $\operatorname{Ig} f-1^{-1-}$ & $n=3$ & $0.051 \pm 0.010$ & +11 & $16.8 \pm 0.2$ & 4 & $527 \pm 23$ & +4 \\
\hline \multicolumn{8}{|l|}{$\mathrm{P} 20$} \\
\hline $\operatorname{Igf}-1^{+/+}$ & $n=5$ & $0.048 \pm 0.003$ & +4 & $16.6 \pm 0.6$ & 3 & $547 \pm 28$ & +8 \\
\hline $\operatorname{Igf}-1^{+/-}$ & $n=3$ & $0.043 \pm 0.003^{e}$ & -6 & $17.6 \pm 0.6$ & 9 & $482 \pm 29^{e}$ & -5 \\
\hline $\operatorname{Ig} f-1^{-1-}$ & $n=5$ & $0.035 \pm 0.003^{f, g}$ & -24 & $13.4 \pm 0.9^{f, g}$ & -17 & $380 \pm 15^{f, g}$ & -25 \\
\hline
\end{tabular}

All data were obtained using stereological methods as described in Materials and Methods and are expressed as mean \pm SD.

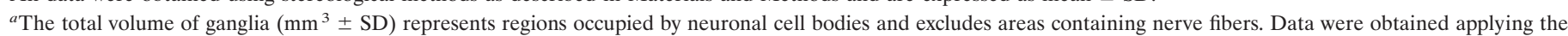
principle of Cavalieri.

${ }^{b}$ The number of neurons in the cochlear ganglion was estimated by means of the "optical fractionator."

${ }^{c}$ Neuronal soma volume $\left(\mu \mathrm{m}^{3} \pm \mathrm{SD}\right)$ was obtained using the "rotator."

${ }^{d}$ Percentual variation with respect to P5 $\operatorname{Ig} f-1^{+/+}$.

${ }^{e}$ Differs from P20 Igf- $l^{+/+} ; p<0.05$.

${ }^{f}$ Differs from P20 Igf- ${ }^{+/+} ; p<0.001$.

${ }^{g}$ Differs from P5 Igf-1 ${ }^{-/-} ; p<0.005$.

growth retardation in the cochlea was less marked and appeared later than the whole body dwarfism.

A detailed analysis of $I g f-1^{-1-}$ cochleas evidenced additional morphological alterations when compared with normal $\operatorname{Ig} f-1^{+/+}$ controls (Fig. 2). The anchorage of the tectorial membrane to the sensory hair cells of the OC in mutant P20 mice is altered with respect to normal mice. During early postnatal development of the mouse inner ear, the tectorial membrane remains firmly attached to the sensory epithelium until the marginal pillars, a glycoprotein structure secreted by Deiters' cells, disappear around P14. It is also by the end of the second postnatal week when the mouse cochlear microarchitecture is considered fully developed and ready for normal auditory function (Rueda et al., 1996). Microscopic examination of the P20 inner ear from Igf$1^{-/-}$mice indicated that in all sections, analyzed from the base to the apex, of the cochlea ( 20 sections from each of the five animals studied), the tectorial membrane remained physically attached to the underlying $\mathrm{OC}$, by a membrane-like structure that may be a remnant of marginal pillars (Fig. $2 B, D$ ). Attachment was also observed in mice of both genotypes at P5, in accordance with their immature state (data not shown). The OC was normal, as judged from the morphological studies performed (Fig. 2). These results indicate that the absence of IGF-1 causes a delay in cochlear development at the level of tectorial membrane maturation.

\section{Reduced total volume, neuronal cell loss, and decreased neuronal cell size in the cochlear ganglion of Igf-1 ${ }^{-1-}$ mice}

Multiple cellular abnormalities were observed in $\operatorname{Ig} f-1^{-1-}$ cochleas at P5 and, more dramatic, at P20 stages. At P5, normal and mutant ganglia presented similar size and cellular densities (Fig. $3 A, B)$, although $\operatorname{Ig} f-1^{-/-}$mice showed a subtype of small cells, with more intense chromatin Nissl staining and non-neuronal appearance (Fig. 3B). At P20, when the sense of hearing is completely functional, ganglia from $I g f-1^{-1-}$ mice showed a severely affected morphology compared with their $I g f-1^{+/+}$littermates. The formers were reduced in size, with fewer neurons and wider intercellular spaces (Fig. $3 C, D$ ). PCNA is a DNA-binding protein required for progression through the $\mathrm{S}$ phase of the cell cycle (Celis and Celis, 1985). Figure 3, $E$ and $F$, shows absence of PCNA expression indicating that cochlear neurons were postmitotic at P5 in both null and normal mice (Fig. 3E,F), whereas cerebellar neurons were actively proliferating at the same age (Fig. $3 G)$.

To further characterize these phenotypic differences, we performed measurements of the cochlear ganglion, as detailed in Materials and Methods. The comparison of P5 Igf-1 $1^{+/+}$with Igf-1 $1^{-/-}$ganglia revealed no significant differences in the three parameters evaluated, ganglion volume, number of neurons, and neuronal cell volume (Table 2 ). In P20 Igf-1 $1^{-/-}$mice, however, all three morphological parameters presented significant reductions with respect to normal mice: $27 \%$ in ganglion volume $(0.035$ vs $\left.0.048 \mathrm{~mm}^{3}\right), 22 \%$ in neuron number $(13,400$ vs 16,$600 ; \sim 3400$ ganglion neurons were lost at P20 from an initial total calculated of 16,800 in $\operatorname{Igf-1^{+/+}}$ at P5), and $31 \%$ in neuronal cell volume $\left(380\right.$ vs $\left.547 \mu \mathrm{m}^{3}\right)$. Comparison of P20 $\operatorname{Ig} f-1^{+/+}$with P5 ganglion cells of either genotype did not show significant changes during this time interval (Table 2). Data on $I g f-1^{+/-}$indicated a moderate decrease in cochlear ganglion volume $(10 \%)$ and in neuronal size $(12 \%)$.

Computerized treatment of the data obtained in the stereological analysis allowed us to study the distribution of the different proportions of neuronal soma sizes. Figure 4 shows the ganglion cellular distribution by cell volumes. By P5, Igf-1 $1^{+/+}$and $I g f-1^{-/-}$ cochlear neurons showed identical proportions of the different cell volumes represented, with most cells $(>80 \%)$ measuring between 300 and $800 \mu \mathrm{m}^{3}$ (Fig. 4). Although the mean neuron cell volume was $\sim 500 \mu \mathrm{m}^{3}$ (Table 2 ), the modal neuronal cell volume was $\sim 425 \mu \mathrm{m}^{3}$. These data indicate that smaller cells were present in higher proportions. At P20, the $I g f-1^{+/+}$cochlear ganglion contained a similar distribution of neuronal soma sizes, but with an increase in the proportion of cells with larger volumes, as indicated by the increase of the mean cell volume to 547 $\mu \mathrm{m}^{3}$ (Table 2). A new subclass of cells appeared with a volume $>950 \mu \mathrm{m}^{3}$, which was not observed in P5 Igf-1 $1^{+/+}$mice (Fig. 4). A logarithmic representation showed that neuronal volume distribution of the P20 Igf-1 $1^{-/-}$ganglion was almost symmetric around the most abundant cell size value, $350-400 \mu \mathrm{m}^{3}$ (data not 


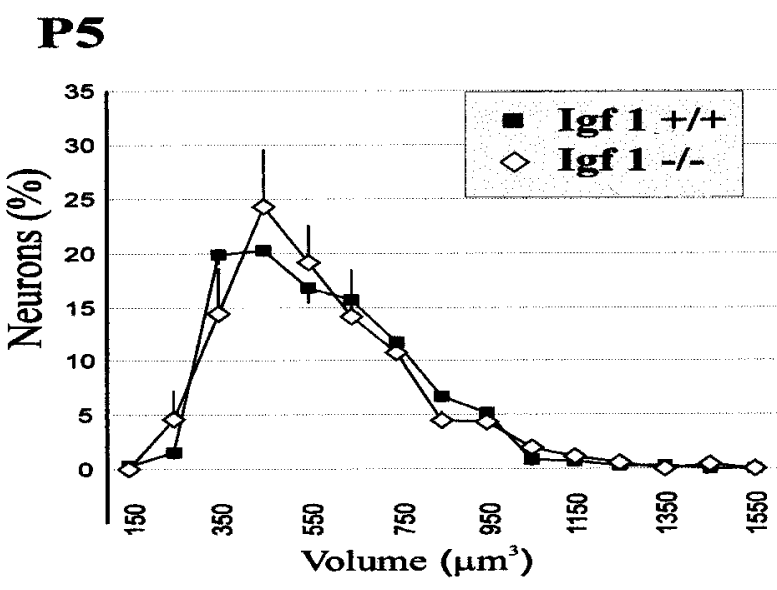

P20

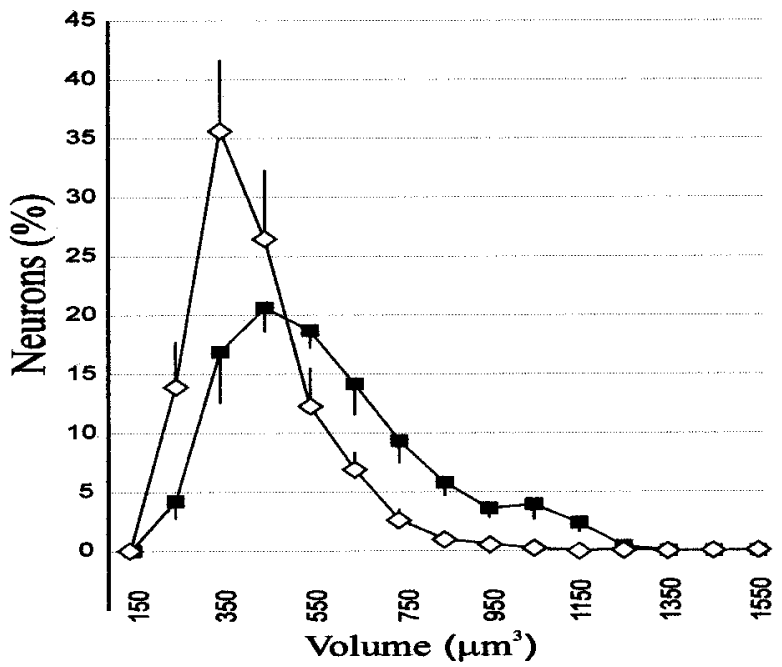

Figure 4. Different perikaryal volume distributions of cochlear ganglion neurons in $\operatorname{Igf-1} 1^{+/+}$and $\operatorname{Igf}-1^{-/-}$mice. Linear plots of data obtained by application of stereological methods (see Materials and Methods) are represented for P5 (top) and P20 (bottom) mice. Error bars represent the SD among animals for each volume class. Whereas the distribution is monomodal in all cases, note the leftward displacement of the curve in the mutant mice at P20, with a marked decrease of cells in the largest size classes. See Table 2 for statistical analysis.

shown; mean, $380 \mu \mathrm{m}^{3}$ ). This result reflects a significant reduction in the number of large ganglion neurons in P20 Igf-1 ${ }^{-/-}$mice compared with their $\operatorname{Ig} f-1^{+/+}$littermates. The former did not display cells larger than $800 \mu \mathrm{m}^{3}$, which represented $10 \%$ of the ganglion neurons in normal animals. In contrast, $75 \%$ of the Igf- $1^{-/-}$neurons were smaller than $400 \mu \mathrm{m}^{3}$, whereas in $\operatorname{Ig} f-1^{+/+}$ animals they only represented $40 \%$. Taken together, these data demonstrate that the absence of IGF-1 during postnatal maturation of the inner ear produces a decrease in the number of cochlear ganglion neurons and reduces their mean soma volume.

To analyze whether neuronal cell loss was attributable to apoptosis, we performed TUNEL labeling and activated caspase-3 detection in Igf-1 $1^{+/+}$and $I g f-1^{-/-}$inner ear paraffin sections at P5, P8, and P20. Normal $\operatorname{Ig} f-1^{+/+}$mice were negative for apoptotic nuclei (Fig. $5 A, E$ ) and activated caspase-3 (Fig. $5 B, F, J)$ across the ages studied $(5,8$, and $20 \mathrm{~d})$. In contrast, in the Igf-1 ${ }^{-1-}$ mice cochleas a significant number of cells were positive with both TUNEL labeling (Fig. $5 C, G, K$ ) and anti-activated caspase-3 immunostaining (Fig. 5D,H,L). Cells positive for ac- tivated caspase-3 decreased in number from P5 to P20, which indicates that most affected cells have disappeared at P20. These data suggest that in the absence of IGF-1 cochlear neurons suffer caspase-3-mediated cell death. The number of apoptotic TUNEL-positive cells decreased from base to apex at P5 and P8 but it increased at P20 (data not shown). Because the structural maturation of the postnatal cochlea proceeds from basal to apical regions, these data suggest that IGF-1 deficit affects more the survival of cells at a more advanced stage of maturation. In parallel, sections of the inner ear from $\operatorname{Ig} f-1^{+/+}$ and $I g f-1^{-/-}$mice were stained with propidium iodide or DAPI. P5 samples from both genotypes showed no differences, whereas P20 Ig $f-1^{-/-}$, but not Igf-1 $1^{+/+}$ganglion cells presented strong staining and nuclear anomalies (data not shown) that may be part of the apoptotic program.

\section{Delayed neural differentiation of postnatal Igf-1 null cochlear ganglion}

To further characterize the cellular abnormalities evidenced by the stereological analysis in the $I g f-1^{-1-}$ cochlea, a panel of differentiation and maturation markers of neurons and glia was tested by immunostaining of sections from normal and mutant cochlear ganglia. Nestin, the intermediate filament characteristic of progenitor cells, showed differential expression at stages P5 and $\mathrm{P} 20$. At $\mathrm{P} 5$, there was no staining in normal $I g f-1^{+/+}$mice (Fig. $6 A$ ), but most $I g f-1^{-/-}$ganglion neurons showed intense expression (Fig. 6B). At P20, none of the genotypes expressed nestin in ganglion neurons; however, nestin was detected in a population of small non-neuronal cells in $I g f-1^{+/+}$animals (Fig. $6 C$ ), but not in the mutants (Fig. $6 D$ ). The scattered pattern of nestin expression detected in $I g f-1^{+/+}$ganglia may correspond to glial cell precursors (Lendahl et al., 1990). The expression pattern of the transcription factor Islet $1 / 2$ in the cochlear ganglion of mutant mice also points to delayed or failed maturation of PCNA-negative postmitotic cells (Fig. $3 E-H)$ ). Islet $1 / 2$ was present at P5 in both genotypes (Fig. $6 E, F$ ), but disappeared in normal $\mathrm{P} 20 \mathrm{Ig} f-1^{+/+}$ mice (Fig. $6 G$ ). In contrast, P20 Igf-1 ${ }^{-/-}$ganglion neurons still expressed this transcription factor (Fig. $6 H$ ).

Immunostaining of cochlear ganglion with synaptophysin evidenced expression of this synaptic marker in almost all neurons at P5 and P20 in both genotypes (Fig. 6I-L). However, the normal P20 Ig $f-1^{+/+}$showed a compact and localized synaptophysin staining pattern, whereas in P20 Igf- $1^{-1-}$ neurons the immunolabeled material covered most of the cell surface in a diff use, less mature pattern (Fig. $6 L$ ). This distinct pattern in the P20 mutant ganglion may reflect altered synaptic refinement in the absence of IGF-1 action. Neurofilament expression was observed at P5, with no differences between genotypes, whereas at P20 Igf-1 $1^{-1-}$ animals showed less staining than $I g f-1^{+/+}$littermates (data not shown).

In most of the bipolar neurons of the postnatal vertebrate cochlear nerve, myelin envelops the axon, the perikaryon, and the dendrite (Toesca, 1996). Because previous studies have reported altered myelination in Igf-1 mutant mice, we used myelin $\mathrm{P}_{0}$ and GFAP antibodies to detect possible alterations in myelination and Schwann cells. At P5, there were no differences in the expression pattern of both markers between genotypes. Myelin $\mathrm{P}_{0}$ immunoreactivity surrounded most ganglion neurons (Fig. $6 M, N$ ), confirming previous data obtained in rats (Toesca, 1996; Knipper et al., 1998), whereas GFAP was undetectable (Fig. 6Q,R). In contrast, at P20 the levels of both antigens were lower in the mutants (Fig. 6P,T) than in the normal mice (Fig. 6O,S), indicating a 


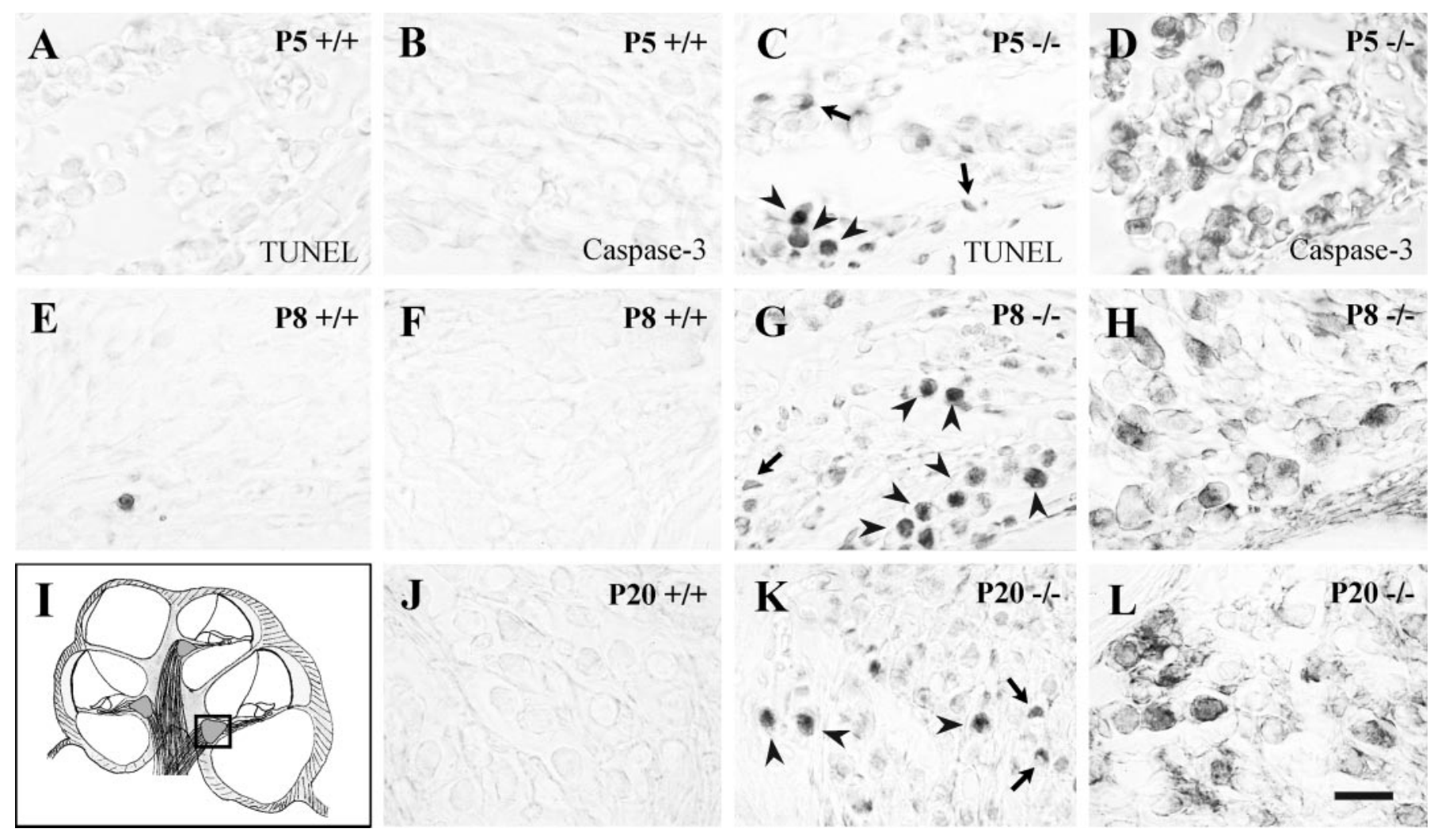

Figure 5. Apoptotic cell death in the cochlear ganglion of $\operatorname{Ig} f-1^{-1-}$ mice. TUNEL labeling $(A, C, E, G, K)$ and detection of activated caspase-3 expression $(B, D, F, H, J, L)$ were performed on paraffin sections from normal $\left(I g f-1^{+/+}\right)$and mutant $\left(\operatorname{Ig} f-1^{-/-}\right)$mice at postnatal days 5,8 , and 20 . The area analyzed is shown in a schematic drawing of the cochlea in which the square indicates basal turn cochlear ganglia $(I)$. Note the increase in apoptotic nuclei $(C, G, K)$ and intense activated caspase-3 immunostaining $(D, H, L)$ in the mutant mice. Arrowheads point to apoptotic neurons, whereas arrows point to dying glial cells. The sections correspond to basal turns of the cochlea. Scale bar, $30 \mu \mathrm{m}$.

deficit in myelination during postnatal cochlear ganglion development of $I g f-1^{-1-}$ mice.

\section{Altered innervation, synaptogenesis, and myelination in the sensory cells of the organ of Corti in Igf-1 mutant mice}

The synaptogenesis and innervation of the OC sensory cells was also altered in Igf-1 $1^{-1-}$ animals (Fig. 7). In rats, anti-synaptophysin antibody labels the synaptic vesicles of the efferent fibers and follows a dynamic expression pattern as synaptic maturation progresses beyond early postnatal stages (Knipper et al., 1995, 1996). In P5 mice, synaptophysin labeled nerve terminals with a similar pattern in both genotypes (Fig. 7A,B). Positive synaptophysin staining appeared with low intensity in nerve fibers from the cochlear ganglion. Staining increased considerably as fibers continue to innervate the base of the sensory cells, forming a diff use "cup-like" shape almost covering the basal half of the cell bodies. The strongest but most diff use staining was localized at the base of the inner hair cells in Igf- $1^{+/+}$animals (Fig. 7A). As synaptogenesis progresses, in P20 hair cells the area of synaptophysin expression was reduced, remaining circumscribed to the basal part of the sensory cells and to discrete points located more distally from the base. In contrast, P20 Igf-1 ${ }^{-1-}$ mice showed stronger, less localized staining (Fig. 7C,D). In these mice, immunopositive presumptive nerve terminals appeared to project synapses up to the supranuclear level of the inner and outer hair cells, resembling the immature situation observed at P5. Neurofilament protein (NF-200 kDa) labeling of the bundle of fibers between the cochlear ganglion and the sensory epithelium pre- sented the same strong expression pattern in both genotypes at P5 (Fig. $7 E, F)$. At P20, Igf-1 $1^{+/+}$fibers showed considerable neurofilament staining (Fig. $7 G$ ), which was notably reduced in Igf$1^{-1-}$, indicating deficits in the density of innervation to the hair cells (Fig. $7 H$ ), and correlating with the defective cochlear neuron survival. The loss in cochlear ganglion neurons produced by IGF-1 deficit also affected the cochlear nerve. In P20 normal mice the nerve showed a continuous fiber-like distribution of neurofilament staining, whereas, on the contrary, P20 Igf-1 ${ }^{-/-}$animals showed less neurofilament staining in a discontinuous patchy distribution and increased levels of vimentin (data not shown). Myelin $\mathrm{P}_{0}$ immunostaining of fibers projecting from the cochlear ganglion to the sensory cells at P5 was similar in normal and mutant animals (Fig. 7I,J), whereas the increase in expression in P20 Igf- $1^{+/+}$cochleas (Fig. $7 K$ ) was not observed in the Igf- $1^{-1-}$ counterparts (Fig. $7 L$ ). Taken together, these data show that the differentiation and maturation of the entire cochlear innervation system is affected by IGF-1 deficit.

\section{DISCUSSION}

The present study demonstrates that IGF-1 absence impairs normal postnatal development of mice cochlear structures. At the whole organ level, we found that the cochleas of P5 $\operatorname{Igf-1^{-1-}}$ mice were similar to those of $I g f-1^{+/+}$. But, from P5 to P20, $I g f-1^{-/-}$ cochlear volume increased by $14 \%$, whereas normal mice cochlear volume increased by $57 \%$. Many, if not all, cochlear structures appeared to be affected. This suggests that the absence of IGF-1 is compensated by alternative factors during embryonic and early 

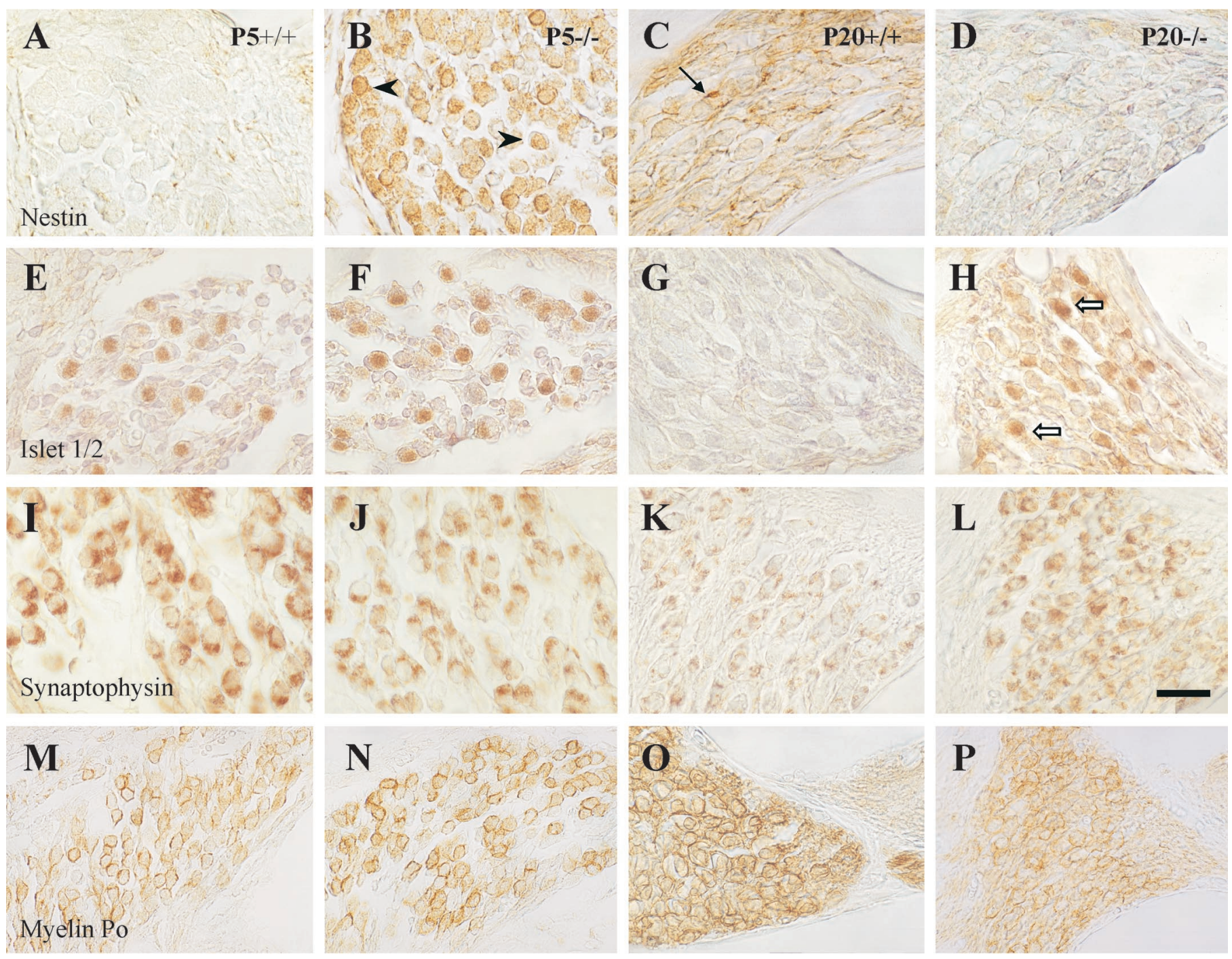

\section{Q}
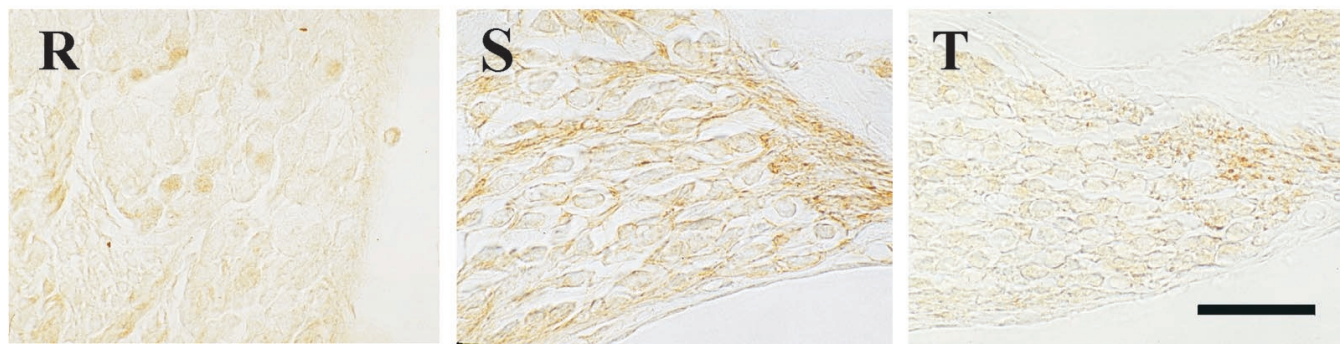

\section{GFAP}

Figure 6. Delayed differentiation of postnatal cochlear ganglion in $I g f-1^{-1-}$ mice. Immunohistochemical analysis of paraffin sections of the cochlear ganglion at midmodiolar levels using nestin $(A-D)$, Islet-1/2 $(E-H)$, synaptophysin $(I-L)$, myelin $\mathrm{P}_{0}(M-P)$, and GFAP $(Q-T)$ antibodies. Left panels $(A$,

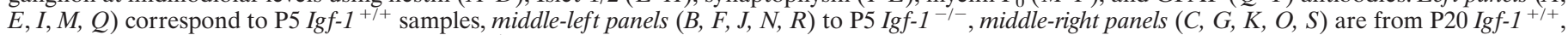
and right panels $(D, H, L, P, T)$ from $\mathrm{P} 20$ Igf-1 $1^{-1-}$ mice. $E-H$ correspond to basal turns of the cochlear ganglion, and the remaining sections in the figure are from apical turns. Scale bars: $A-L, 40 \mu \mathrm{m} ; M-T, 30 \mu \mathrm{m}$.

postnatal cochlear development, but cochlear growth is IGF-1dependent at later stages. Igf-1 nullizygous mice display postnatal general growth retardation with organ-specific size alterations (Liu et al., 1993). For example, adult brain is less affected by the growth deficit $(\sim 30 \%)$ than whole body $(\sim 60 \%)$ (Cheng et al., 1998). To our knowledge, no organ has been studied early enough to know if there is normal growth before P5 as we report for the cochlea (Powell-Braxton et al., 1993; Beck et al., 1995; Wang et al., 1999a).

At the cellular level, the actions of IGF-1 appeared to be diverse. Cochlear ganglia cellular content was reduced by $22 \%$, and the mean size of the sensory neurons of the cochlear ganglia was also reduced in the knock-out mice at P20. Cochlear ganglion neurons suffered a mean size reduction in the range of that described for other cell types. Thus, chondrocytes from bone growth plates and testicular Leydig $I g f-1^{-/-}$cells show size reduction, attributed to their delayed developmental stage (Baker et al., 1996; Wang et al., 1999b). Proliferating mutant uterine cells also present a $20-40 \%$ decrease in cell size and augmented DNA content, associated to slow progression through the cell cycle 

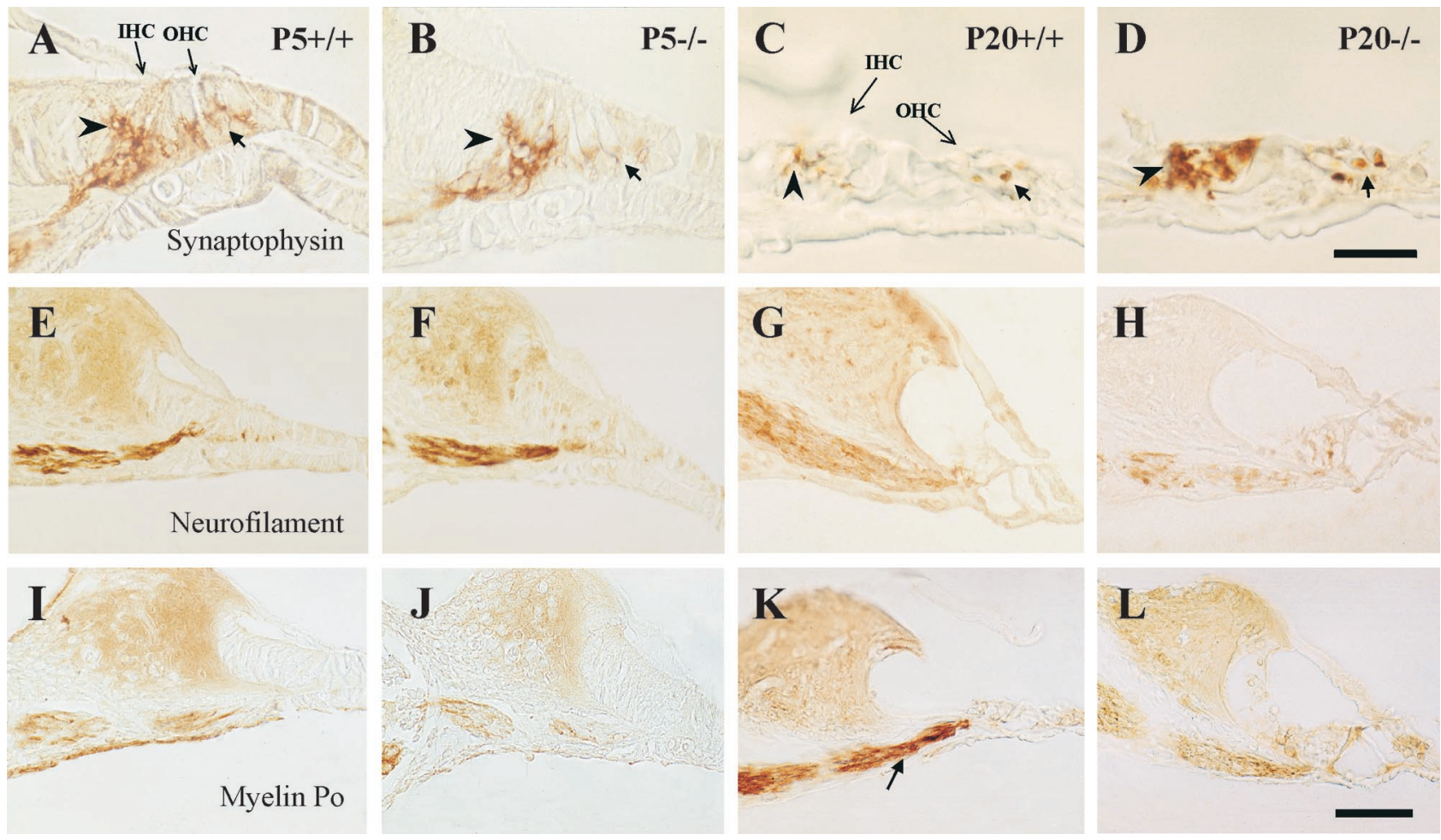

Figure 7. Differential expression of neural and glial markers in the innervation of the organ of Corti. Immunohistochemical staining of midmodiolar paraffin sections of basal turns of the cochlea with synaptophysin $(A-D)$, neurofilament $200 \mathrm{kDa}(E-H)$, and myelin $\mathrm{P}_{0}(I-L)$ antibodies. Left panels $(A$, $E, I)$ correspond to $\mathrm{P} 5 \mathrm{Ig} f-1^{+/+}$samples, middle-left panels $(B, F, J)$ to $\mathrm{P} 5 \mathrm{Igf-1^{-1- }}$, middle-right panels $(C, G, K)$ to $\mathrm{P} 20$ Igf- $1^{+/+}$, and right panels $(D$, $H, L)$ to P20 Igf-1 $1^{-1-}$ mice. At P5 $(A, B)$, synaptophysin immunoreactivity appears diff use and displays a "cup-like" shape surrounding the IHCs (arrowheads) and OHCs (arrows). At P20 $(C, D)$, the synaptophysin staining pattern is better defined at the base of IHC and nerve fibers in the Igf- $1^{+/+}$ controls than in Igf-1 $1^{-1-}$ mutants. NF-200K and myelin $\mathrm{P}_{0}$ immunostainings do not evidence major differences at P5 but are clearly less intense in P20 $I g f-1^{-1-}$ mice $(H, L)$ than in $I g f-1^{+/+}$controls $(G, K$, arrow $)$. Scale bars: $A-D, 20 \mu \mathrm{m} ; E-L, 30 \mu \mathrm{m}$.

(Adesanya et al., 1999). In a mirror image, IGF-1 P7 transgenic mice present increased cell size in the hippocampal dentate gyrus (O'Kusky et al., 2000). Cell size is regulated by a complex net of transduction pathways (Conlon and Raff, 1999), where the participation of an insulin/IGF receptor substrate has been shown even in Drosophila, in which mutant cells were fewer and smaller than normal (Bohni et al., 1999).

Transient IGF-1 gene expression has been reported during the maturation of the mice auditory sensory relay system (Bondy, 1991). Here, we show the local expression of IGF-1 in cochlear structures including a subpopulation of cochlear ganglion neurons, stria vascularis, spiral limbus, and support cells of the OC. Therefore, the alterations observed in inner ear structures may be attributable to the local deficit of IGF-1 actions superimposed to the lack of circulating IGF-1 (Trejo et al., 2001).

In our study, both mutant and normal cochlear ganglia have similar numbers of postmitotic neurons at P5, but $I g f-1^{-1-}$ mice showed a considerable loss of ganglion neurons from P5 to P20, a time frame in which IGF-1 action appears to be critical for survival of cochlear neurons. This cell loss was attributable to apoptosis accompanied by an increased number of neurons expressing activated caspase-3, a protease implicated in neural cell death as deduced from the caspase- 3 mutant mice that present decreased apoptosis in the brain (Kuida et al., 1996). Apoptosis caused by IGF-1 deficit was more intense in cells of the basal turn of the cochlea, the more mature region, whose development proceeds from base to apex (Mikaelian and Ruben, 1964). Therefore, IGF-1 should be included in the list of previously described trophic factors required for mouse auditory neurons survival (Fekete, 1999; Bussoli and Steel, 2001), which all together must cooperate postnatally in modulating the number of neurons in the cochlear ganglion.

Our results also demonstrate that IGF-1 action is required for timely differentiation and maturation of the cochlea. Two major morphological alterations were observed in the P20 Igf- 1 mutants. The first was the presence of a thicker cartilaginous otic capsule in the Igf-1 $1^{-1-}$ cochlea, confirming studies that reported retarded ossification (Baker et al., 1993). The second was a firmer anchoring of the tectorial membrane to the $\mathrm{OC}$ by the abnormal permanence of the marginal pillars, a transitory laminar structure that disappears at $\sim \mathrm{P} 14$ in normal mice. A fully functional tectorial membrane is required for an appropriate gain and timing of cochlear feedback (Legan et al., 2000). The immature permanence of the marginal pillars in P20 limit relative mechanical motion between the tectorial membrane and the hair cells, thus creating higher thresholds than in the normal cochlea (Romand et al., 1987; Rueda et al., 1996). Permanent attachment and severe distortion of the tectorial membrane were reported in hypothyroid rats (Uziel et al., 1983; Prieto et al., 1990). Because it has been reported that adult IGF-1 mutant animals might hear loud noises (Cheng et al., 1998), the evaluation of the impact of the abnormalities shown in the present study on frequency thresholds will need future electrophysiological analysis.

A delayed developmental pattern was also observed in the cochlear ganglia of IGF-1 deficient mouse. Differentiation of Ig $f-1^{-1-}$ cochlea was evaluated with the markers nestin and 
Islet-1/2. Nestin is a marker for neural precursor cells (Lendahl et al., 1990), whereas Islet transcription factors play important roles in neuronal differentiation (Tsuchida et al., 1994). Cochlear ganglion cells are postmitotic but cells that have recently withdrawn from the cell cycle can still be nestin positive (Vicario-Abejón et al., 1995). Therefore, P5 Igf-1 ${ }^{-/-}$nestin-positive cells supported the presence of neuroblasts, delayed in developmental stage compared with P5 Igf-1 $1^{+/+}$counterparts. Altered Islet 1/2 expression confirmed the delayed developmental pattern.

Our results indicate that absence of IGF-1 causes increased apoptosis, a decrease in neuronal size, and abnormal neuronal differentiation. Damage of cochlear ganglion neurons may be deleterious to hair cells and vice versa (Ryan, 2000), leaving open the possibility that the alterations described in Igf-1 $1^{-/-}$cochlear neurons could lead to damage in hair cells. In fact, P20 Igf-1 $1^{-/-}$ mutant animals maintained innervation to the cochlear sensory cells, but their synapses were altered, either because of a delay in differentiation or refining, or because they tried to compensate the deficit of innervation because of neuronal loss. The cochlear nerve showed a dispersed fiber phenotype in the center of the cochlea, associated with decreased neurofilament protein expression in nerve fibers. Mice with mutations in neurofilament genes have reduced axonal diameters, a phenotype previously described in Igf-1 mutant nerves (Hirokawa, and Takeda, 1998; Gao et al., 1999). Synaptophysin expression in normal cochlear ganglion and OC was similar to that reported in the rat inner ear (Knipper et al., 1995, 1996). The alterations observed in $I g f-1^{-1-}$ cochlea might reflect transient growth of immature synaptic processes. Therefore, the local presence of IGF-1 would be required during this critical period for neuronal connections. It has been reported that a coordinated process of axonal growth and synaptogenesis takes place at P9 in rodents, probably as a consequence of competition for the sensory epithelium (Pujol, 1986). In the dentate gyrus, IGF-1 overexpression produces increases in the total number of synapses (O'Kusky et al., 2000), thus confirming that IGF-1 supports synaptogenesis during mice postnatal development.

Myelination in $I g f-1^{-/-}$cochlear fibers was also delayed or altered, as reflected by the expression of myelination markers. The myelination of the cochlear ganglia sensory neurons occurs postnatally (Schwartz et al., 1983). At P20, The reduction in the level of myelin $\mathrm{P}_{0}$ was dramatic. Previous studies on hypothyroid rats also show decreased myelin $\mathrm{P}_{0}$ mRNA levels in the cochlear ganglion and hair cell innervation (Knipper et al., 1998). Interestingly, myelin protein $\mathrm{P}_{0}$ is an autoantigen in human autoimmune inner ear disease (Cao et al., 1996). The innervation of the OC has been proposed as critical for neuronal survival and postnatal development of cochlear sensitivity (Ernfors et al., 1995; Bruce et al., 2000). These results are in agreement with earlier studies on mice with a different $I g f-1$ targeted mutation, showing that $I g f-1$ gene disruption produces loss of certain neuronal subpopulations, a general decrease in axonal diameters, selective hypomyelination, and reduced nerve conduction velocities in vivo (Beck et al., 1995; Cheng et al., 1998; Gao et al., 1999). Furthermore, selective overexpression of IGF-1 in brain causes an increase in neuron number, total brain myelin, and regional density of myelinated axons (Behringer et al., 1990; Carson et al., 1993; Ye et al., 1995).

In summary, we have shown that IGF-1-deficient mice had a size reduction of the cochlea and cochlear ganglion, an immature tectorial membrane, and a significant decrease in the number and size of auditory neurons. Analysis of key markers demonstrated that lack of IGF-1 produces a general delay in differentiation of the cochlear ganglion cells during postnatal development. Cochlear ganglion fibers presented decreased myelination, abnormal synaptogenesis, and deficient innervation of the sensory cells in the OC. This cochlear phenotype provides basis to understand one of the mechanisms leading to sensorineural deafness, as found in the human patient with a homozygous $I g f-1$ gene deletion (Woods et al., 1996, 1997). Our findings further support the inclusion of IGF-1 among the essential neurotrophic factors to be considered as molecules with potential therapeutic value.

\section{REFERENCES}

Adesanya OO, Zhou J, Samathanam C, Powell-Braxton L, Bondy CA (1999) Insulin-like growth factor 1 is required for G2 progression in the estradiol-induced mitotic cycle. Proc Natl Acad Sci USA 96:3287-3291.

Avendaño C, Dykes RW (1996) Quantitative analysis of anatomical changes in the cuneate nucleus following forelimb denervation: a stereological morphometric study in adult cats. J Comp Neurol 370:491-500.

Baker J, Liu JP, Robertson EJ, Efstratiadis A (1993) Role of insulin-like growth factors in embryonic and postnatal growth. Cell 75:73-82.

Baker J, Hardy MP, Zhou J, Bondy C, Lupu F, Bellve AR, Efstratiadis A (1996) Effects of an Igf1 gene null mutation on mouse reproduction. Mol Endocrinol 10:903-918.

Beck KD, Powell-Braxton L, Widmer HR, Valverde J, Hefti F (1995) Igf1 gene disruption results in reduced brain size, CNS hypomyelination, and loss of hippocampal granule and striatal parvalbumincontaining neurons. Neuron 14:717-730.

Behringer RR, Lewin TM, Quaife CJ, Palmiter RD, Brinster RL, D'Ercole AJ (1990) Expresion of insulin-like growth I stimulates normal somatic growth in growth hormone-deficient transgenic mice. Endocrinology 127:1033-1040.

Berglund AM, Ryugo DK (1987) Hair cell innervation by spiral ganglion neurons in the mouse. J Comp Neurol 255:560-570.

Blasco B, Avendaño C, Cavada C (1999) A stereological analysis of the lateral geniculate nucleus in adult Macaca nemestrina monkeys. Vis Neurosci 16:933-941.

Bohni R, Riesgo-Escovar J, Oldham S, Brogiolo W, Stocker H, Andruss BF, Beckingham K, Hafen E (1999) Autonomous control of cell and organ size by CHICO, a Drosophila homolog of vertebrate IRS1-4. Cell 97:865-875.

Bondy CA (1991) Transient IGF-I gene expression during the maturation of functionally related central projection neurons. J Neurosci 11:3442-3455.

Bruce LL, Christensen MA, Warr WB (2000) Postnatal development of efferent synapses in the rat cochlea. J Comp Neurol 423:532-548.

Bussoli TJ, Steel KP (2001) World wide web URL:http:/www.ihr. mrc.ac.uk.

Cao MY, Dupriez VJ, Rider MH, Deggouj N, Gersdorff MC, Rousseau GG, Tomasi JP (1996) Myelin protein Po as a potential autoantigen in autoimmune inner ear disease. FASEB J 10:1635-1640.

Carson MJ, Behringer RR, Brinster RL, McMorris FA (1993) Insulinlike growth factor I increases brain growth and central nervous system myelination in transgenic mice. Neuron 10:729-740.

Celis JE, Celis A (1985) Cell cycle-dependent variations in the distribution of the nuclear protein cyclin proliferating cell nuclear antigen in cultured cells: subdivision of $\mathrm{S}$ phase. Proc Natl Acad Sci USA 82:3262-3266.

Cheng CM, Joncas G, Reinhardt RR, Farrer R, Quarles R, Janssen J, McDonald MP, Crawley JN, Powell-Braxton L, Bondy CA (1998) Biochemical and morphometric analyses show that myelination in the insulin-like growth factor 1 null brain is proportionate to its neuronal composition. J Neurosci 18:5673-5681.

Colucci-Guyon E, Portier MM, Dunia I, Paulin D, Pournin S, Babinet C (1994) Mice lacking vimentin develop and reproduce without an obvious phenotype. Cell 79:679-694.

Conlon I, Raff M (1999) Size control in animal development. Cell 96:235-244.

D'Ercole AJ, Ye P, Calikoglu AS, Gutierrez-Ospina G (1996) The role of the insulin-like growth factors in the central nervous system. Mol Neurobiol 13:227-255.

Dore S, Kar S, Quirion R (1997) Rediscovering an old friend, IGF-I: potential use in the treatment of neurodegenerative diseases. Trends Neurosci 20:326-331.

Ernfors P, Van de Water T, Loring J, Jaenisch R (1995) Complementary roles of BDNF and NT-3 in vestibular and auditory development. Neuron 14:1153-1164.

Fekete DM (1999) Development of the vertebrate ear: insights from knockouts and mutants. Trends Neurosci 22:263-269. 
Gao WQ, Shinsky N, Ingle G, Beck K, Elias KA, Powell-Braxton L (1999) IGF-I deficient mice show reduced peripheral nerve conduction velocities and decreased axonal diameters and respond to exogenous IGF- I treatment. J Neurobiol 39:142-152.

Gundersen HJ, Bendtsen TF, Korbo L, Marcussen N, Møller A, Nielsen K, Nyengaard JR, Pakkenberg B, Sørensen FB, Vesterby A (1988) Some new, simple and efficient stereological methods and their use in pathological research and diagnosis. APMIS 96:379-394.

Hirokawa N, Takeda S (1998) Gene targeting studies begin to reveal the function of neurofilament proteins. J Cell Biol 143:1-4.

Hogan B, Beddington R, Constantini F, Lacy E (1994) Manipulating the mouse embryo: a laboratory manual. Cold Spring Harbor, NY: Cold Spring Harbor Laboratory.

Howard CV, Reed MG (1998) Unbiased stereology. Three-dimensional measurement in microscopy. Oxford: BIOS Scientific.

Jensen EBV, Gundersen HJG (1993) The rotator. J Microsc 170:35-44.

Knipper M, Zimmermann U, Rohbock K, Kopschall I, Zenner HP (1995) Synaptophysin and GAP-43 proteins in efferent fibers of the inner ear during postnatal development. Brain Res 89:73-86.

Knipper M, Zimmermann U, Rohbock K, Kopschall I, Zenner HP (1996) Expression of neurotrophin receptor trkB in rat cochlear hair cells at time of rearrangement of innervation. Cell Tissue Res 283:339-353.

Knipper M, Bandtlow C, Gestwa L, Kopschall I, Rohbock K, Wiechers B, Zenner HP, Zimmermann U (1998) Thyroid hormone affects Schwann cell and oligodendrocyte gene expression at the glial transition zone of the VIIIth nerve prior to cochlea function. Development 125:3709-3718.

Kuida K, Zheng TS, Na S, Kuan CY, Yang D, Karasuyama H, Rakic P, Flavell RA (1996) Decreased apoptosis in the brain and premature lethality in CPP32-deficient mice. Nature 384:368-372.

Lagares A, Avendaño C (2000) Lateral asymmetries in the trigeminal ganglion of the male rat. Brain Res 865:202-210.

Lee KH, Cotanche DA (1996) Potential role of bFGF and retinoic acid in the regeneration of chicken cochlear hair cells. Hear Res 94:1-13.

Legan PK, Lukashkina VA, Goodyear RJ, Kössi M, Russell IJ, Richardson GP (2000) A targeted deletion in alfa-tectorin reveals that the tectorial membrane is required for the gain and timing of cochlear feedback. Neuron 28:273-285.

Lendahl U, Zimmerman LB, McKay RD (1990) CNS stem cells express a new class of intermediate filament protein. Cell 60:585-595.

León Y, Vazquez E, Sanz C, Vega JA, Mato JM, Giraldez F, Represa J, Varela-Nieto I (1995) Insulin-like growth factor-I regulates cell proliferation in the developing inner ear, activating glycosylphosphatidylinositol hydrolysis and Fos expression. Endocrinology 136:3494-3503.

León Y, Sanz C, Frago LM, Camarero G, Canon S, Varela-Nieto I, Giraldez F (1999) Involvement of insulin-like growth factor-I in inner ear organogenesis and regeneration. Horm Metab Res 31:126-132.

Liu JL, Grinberg A, Westphal H, Sauer B, Accili D, Karas M, LeRoith D (1998) Insulin-like growth factor-I affects perinatal lethality and postnatal development in a gene dosage-dependent manner: manipulation using the Cre/loxP system in transgenic mice. Mol Endocrinol 12:1452-1462.

Liu JP, Baker J, Perkins AS, Robertson EJ, Efstratiadis A (1993) Mice carrying null mutations of the genes encoding insulin-like growth factor I (Igf-1) and type 1 IGF receptor (Igflr). Cell 75:59-72.

Mu MY, Chardin S, Avan P, Romand R (1997) Ontogenesis of rat cochlea. A quantitative study of the organ of Corti. Brain Res Dev Brain Res 99:29-37.

Mikaelian D, Ruben RJ (1964) Development of hearing in the normal CBA-J mouse. Acta Otolaryngol 59:451-461.

Oesterle EC, Tsue TT, Rubel EW (1997) Induction of cell proliferation in avian inner ear sensory epithelia by insulin-like growth factor-I and insulin. J Comp Neurol 380:262-274.

O'Kusky JR, Ye P, Dércole AJ (2000) Insulin-like growth factor-1 promotes neurogenesis and synaptogenesis in the hippocampal dentate gyrus during postnatal development. J Neurosci 20:8435-8442.

Powell-Braxton L, Hollingshead P, Warburton C, Dowd M, Pitts-Meek S, Dalton D, Gillett N, Stewart TA (1993) IGF-I is required for normal embryonic growth in mice. Genes Dev 7:2609-2617.

Prieto JJ, Rueda J, Sala ML, Merchan JA (1990) Lectin staining of saccharides in the normal and hypothyroid developing organ of Corti. Brain Res Dev Brain Res 52:141-149.
Pujol R (1986) Synaptic plasticity in the developing cochlea. In: The biology of change in otolaryngology (Ruben RW, DeWater TV, Rubel EW, eds), pp 47-54. Amsterdam: Elsevier.

Romand R, Despres G, Giry N (1987) Factors affecting the onset of inner ear function. Hear Res 28:1-7.

Rubel EW (1978) Ontogeny of structure and function in the vertebrate's auditory system. In: Development of sensory systems (Jacobson M, ed), pp 135-247. New York: Springer.

Rueda J, Cantos R, Lim DJ (1996) Tectorial membrane-organ of Corti relationship during cochlear development. Anat Embryol 194:501-514.

Ryan AF (2000) Protection of auditory receptors and neurons: evidence for interactive damage. Proc Natl Acad Sci USA 97:6939-6940.

Saffer LD, Gu R, Corwin JT (1996) An RT-PCR analysis of mRNA for growth factor receptors in damaged and control sensory epithelia of rat utricles. Hear Res 94:14-23.

Sanz C, León Y, Canon S, Alvarez L, Giraldez F, Varela-Nieto I (1999a) Pattern of expression of the jun family of transcription factors during the early development of the inner ear: implications in apoptosis. J Cell Sci 112:3967-3974.

Sanz C, León Y, Troppmair J, Rapp UR, Varela-Nieto I (1999b) Strict regulation of c-Raf kinase levels is required for early organogenesis of the vertebrate inner ear. Oncogene 18:429-437.

Schwartz AM, Parakkal M, Gulley RL (1983) Postnatal development of spiral ganglion cells in the rat. Am J Anat 167:33-41.

Spoendlin H (1988) Neural anatomy of the inner ear. In: Physiology of the ear (Jahn AF, Santos-Sachi J, eds), pp 201-219. New York: Raven.

Staecker H, Van de Water TR (1998) Factor controlling hair-cell regeneration/repair in the inner ear. Curr Opin Neurol 8:480-487.

Sterio DC (1984) The unbiased estimation of number and sizes of arbitrary particles using the disector. J Microsc 134:127-136.

Srinivasan A, Roth KA, Sayers RO, Shindler KS, Wong AM, Fritz LC, Tomaselli KJ (1998) In situ immunodetection of activated caspase-3 in apoptotic neurons in the developing nervous system. Cell Death Diff 5:1004-1016.

Tandrup T, Gundersen HJG, Jensen EBV (1997) The optical rotator. J Microsc 186:108-120.

Toesca A (1996) Central and peripheral myelin in the rat cochlear and vestibular nerves. Neurosci Lett 221:21-24.

Trejo JL, Carro E, Torres-Alemán I (2001) Circulating Insulin-like growth factor I mediates exercise-induced increases in the number of new neurons in the adult hippocampus. J Neurosci 21:1628-1634.

Tsuchida T, Ensini M, Morton SB, Baldassare M, Edlund T, Jessell TM, Pfaff SL (1994) Topographic organization of embryonic motor neurons defined by expression of LIM homeobox genes. Cell 79:957-970.

Uziel A, Legrand C, Ohresser M, Marot M (1983) Maturational and degenerative processes in the organ of Corti after neonatal hypothyroidism. Hear Res 11:203-218.

Vicario-Abejón C, Johe KK, Hazel TG, Collazo D, McKay RDG (1995) Functions of basic fibroblasts growth factor and neurotrophins in the differentiation of hippocampal neurons. Neuron 15:105-114.

Wang J, Zhou J, Powell-Braxton L, Bondy C (1999a) Effects of Igf1 gene deletion on postnatal growth patterns. Endocrinology 140:3391-3394.

Wang J, Zhou J, Bondy CA (1999b) Igf1 promotes longitudinal bone growth by insulin-like actions augmenting chondrocyte hypertrophy. FASEB J 13:1985-1990.

West MJ (1999) Stereological methods for estimating the total number of neurons and synapses: issues of precision and bias. Trends Neurosci 22:51-61.

West MJ, Slomianka L, Gundersen HJG (1991) Unbiased stereological estimation of the total number of neurons in the subdivisions of the rat hippocampus using the optical fractionator. Anat Rec 231:482-497.

Woods KA, Camacho-Hubner C, Savage MO, Clark AJ (1996) Intrauterine growth retardation and postnatal growth failure associated with deletion of the insulin-like growth factor I gene. N Engl J Med 335:1363-1367.

Woods KA, Camacho-Hubner C, Barter D, Clark AJ, Savage MO (1997) Insulin-like growth factor I gene deletion causing intrauterine growth retardation and severe short stature. Acta Pediatr [Suppl] 423:39-45.

Ye P, Carson J, D’Ercole AJ (1995) In vivo actions of insulin-like growth factor-I (IGF-I) on brain myelination: studies of IGF-I and IGF binding protein-1 (IGFBP-1) transgenic mice. J Neurosci 15:73447356. 